\title{
PERAN SERIAL NETFLIX SEX EDUCATION SEBAGAI PEMBELAJARAN REMAJA JENJANG SMA DI INDONESIA
}

\begin{tabular}{|c|}
\hline Muhammad Azhari Mutaqin \\
\hline $1910128210020 @$ mhs.ulm.ac.id \\
Program Studi Pendidikan IPS FKIP, Universitas Lambung Mangkurat \\
\hline
\end{tabular}

\begin{abstract}
This article aims to describe the role of the Netflix Sex Education series as material for learning and adding insight to high school youth in Indonesia. In this study, the author uses qualitative methods by conducting interviews and literature studies based on the problems discussed, namely the Role of the Netflix Sex Education Series as Learning for High School Teens in Indonesia. The results of this study show that this series provides the right portion to discuss each of the supporting characters with all their problems. Each of their problems raises relevant contemporary issues about how teenagers find their identity. Based on the results of the interviews, it can be seen that this series can be used as a lesson because there is a lot of information about sexual education in which the role is related to the curiosity of teenagers through the provision of information related to sexuality.
\end{abstract}

Keywords: Sex Education, Learning, Youth

\begin{abstract}
ABSTRAK
Artikel ini memiliki tujuan untuk memaparkan peran serial Netflix Sex Education sebagai bahan untuk pembelaran dan penambahan wawasan remaja SMA di Indonesia. Pada penelitian ini penulis menggunakan metode kualitatif dengan melakukan wawancara dan studi pustaka berdasarkan permasalahan yang dibahas yakni Peran Serial Netflix Sex Education Sebagai Pembelajaran Remaja Jenjang SMA di Indonesia. Pada hasil penelitian ini menampilkan bahwa serial ini memberikan porsi yang pas untuk membahas masing-masing karakter pendukung dengan segala permasalahan mereka. Setiap permasalahan mereka mengangkat isu kekinian yang relevan tentang bagaimana remaja mencari jati diri mereka. Berdasarkan dari hasil wawancara, dapat dilihat bahwa serial ini bisa dijadikan pembelajaran sebab terdapat banyak informasi tentang pendidikan seksual yang mana peran tersebut terkait dengan perasaan ingin tahu remaja melalui pemberian informasi yang berkaitan dengan seksualitas.
\end{abstract}

Kata Kunci: Sex Education, Pembelajaran, Remaja 


\section{PENDAHULUAN}

Pendidikan tentu saja erat kaitannya dengan pembelajaran, adapun pembelajaran secara umum bisa bersumber dari mana saja. Pembelajaran merupakan suatu kegiatan yang berupaya membelajarkan peserta didik secara terintegrasi dengan memperhitungkan faktor lingkungan belajar, karakteristik siswa, karakteristik bidang studi serta berbagai strategi pembelajaran, baik penyampaian, pengelolaan maupun pengorganisasian pembelajaran. Pembelajaran pada hakekatnya adalah proses interaksi antara peserta didik dengan lingkungan, sehingga terjadi perubahan ke arah yang lebih baik (Handy, 2021). Interaksi tersebut banyak sekali faktor yang mempengaruhinya, baik faktor internal yang datang dari dalam diri individu maupun faktor eksternal yang datang dari lingkungan.

Saat ini jenjang Sekolah Menengah Atas atau jika dibahasakan secara global yakni Senior High School menjadi jenjang yang sangat rawan akan kenakalan remaja. Sebab masa remaja merupakan masa yang penuh rasa ingin tahu terhadap segala hal, termasuk salah satunya masalah seksual. Pada masa ini remaja membutuhkan bimbingan dalam bentuk pendidikan seksual dalam pembentukan pribadinya baik dengan orangtua maupun lingkungan. Pendidikan seksual ini juga termasuk dalam hubungan baru yang lebih matang dengan lawan jenis. Pada masa ini informasi tentang masalah seksual sudah seharusnya mulai diberikan untuk menghindari agar remaja tidak mencari informasi sendiri dari teman atau sumber lain yang tidak jelas atau bahkan keliru sama sekali.

Sumber belajar bisa didapatkan dari mana saja termasuk dari menonton sebuah film yang mengandung banyak pesan moral (Abbas, 2021). Sehubung dengan hal ini, perusahaan penyedia layanan media streaming digital asal California Bernama Nelfix merilis sebuah serial yang berjudul Sex Education (Blea, 2020). Serial Sex Education adalah serial televisi komedi-drama asal Inggris dibuat oleh Laurie Nunn, ditayangkan perdana pada 11 Januari 2019 di Netflix. Pada bulan Februari 2019, diumumkan bahwa serial telah diperbarui untuk musim kedua yang tayang pada 17 Januari 2020. Sehubung dengan penjelasan di atas, series ini bisa dijadikan sebegai bahan pembelajaran untuk remaja jenjang Sekolah Menengah Atas khususnya di Indonesia. Artikel ini di buat dengan tujuan memahami dan mengetahui peran dari serial Sex Education yang bisa menjadi media belajar dalam bentuk visual dan bisa menjadi edukasi kepada para remaja sekolah untuk mengetahui betapa pentingnya pendidikan seksesual, orientasi seksual, dampak dari sex yang tidak aman, serta dampak dari sex bebas. 


\section{METODE PENELITIAN}

Metode yang digunakan penulis yakni menggunakan metode kajian kepustakaan dan metode wawancara serta menggunakan penelitian kualitatif. Kajian kepustakaan merupakan proses pencarian informasi yang berhubungan dengan topik yang menjadi pembahasan utama penelitian. Untuk memperoleh informasi tersebut, peneliti bisa mendapatkannya melalui karya ilmiah, buku-buku, skripsi, tesis, disertasi, internet dan sumber relavan lainnya. Sedangkan metode wawancara yakni membuat sebuah pertanyaan yang diberikan kepada pelaku yang berkaitan dengan judul artikel. Penulis melakukan beberapa wawancara singkat kepada beberapa remaja jenjang SMA di Indonesia yang pernah menonton serial Netlfix berjudul Sex Education. Adapun pada penelitian kualitatif digunakan karena penulis ingin menelaah lebih lanjut mengenai peran serial Netflix berjudul Sex Education sebagai bahan pembelajaran remaja jenjang SMA di Indonesia dengan cara mendeskripsikan dalam bentuk kalimat, dengan sebuah konteks alamiah serta memanfaatkan beberapa metode alamiah.

\section{HASIL DAN PEMBAHASAN}

Remaja merupakan salah satu komponen dari gatra demografi pada astagatra ketahanan nasional, memiliki pengaruh yang besar bagi keberlangsungan kehidupan Indonesia (Rusmaniah, 2021). Jika Indonesia berhasil mendidik para remajanya saat ini untuk mampu mengekspresikan gairah masa mudanya dengan hal yang positif, jauh dari perilaku seksual pranikah, dan bertanggung jawab penuh dengan aktivitas seksualnya baik dari segi agama, biologi, dan moral, maka sangat mungkin Indonesia di masa depan akan menjadi negara yang sejahtera. Namun tidak ada yang bisa diharapkan jika remaja Indonesia sibuk dengan perilaku seks bebas dan perilaku seksual pranikah.

Teknologi terus berkembang seiring perkembangan globalisasi yang menyebabkan semua orang bisa mengakses semuanya (Abbas, 2019). Secara harfiah kalangan yang sangat menguasai teknologi adalah para rentan usia muda. Sehubung dengan hal di atas, penulis melakukan wawancara dari berbagai remaja di Indonesia yang mana mereka memberikan reaksi dan tanggapan setelah menonton serial Sex Education pada season pertama. Serial Sex Education pada season pertama bercerita tentang Otis (Asa Buterfield), remaja 16 tahun yang terlambat berkembang dan tidak begitu tertarik dengan seks, berbeda dari remaja seumurannya. Walaupun begitu, ia memiliki pengetahuan yang banyak tentang perkara seksual karena ibunya (Gillian Anderson) 
adalah seorang psikolog seks. Teman satu sekolahnya, Maeve (Emma Macky) melihat pengetahuan Otis ini sebagai sebuah prospek menjanjikan dan mereka pun membuka sebuah klinik seks berbayar untuk membantu anak-anak di sekolah mereka dengan segala macam masalah seksualnya. Serial Sex Education lebih menonjolkan apa yang dialami para remaja di Inggris semasa berasa di jenjang Sekolah Menengah Atas berdasarkan fakta tanpa pemanis seperti cerita fiksi kebanyakan (Forni, 2020). Adapun yang diperlihatkan mulai dari hubungan seks, orientasi seksual, persahabatan, hingga masalah keluarga ditampilkan dengan sangat terang-terangan dan canggung layaknya kelas pendidikan seksual.

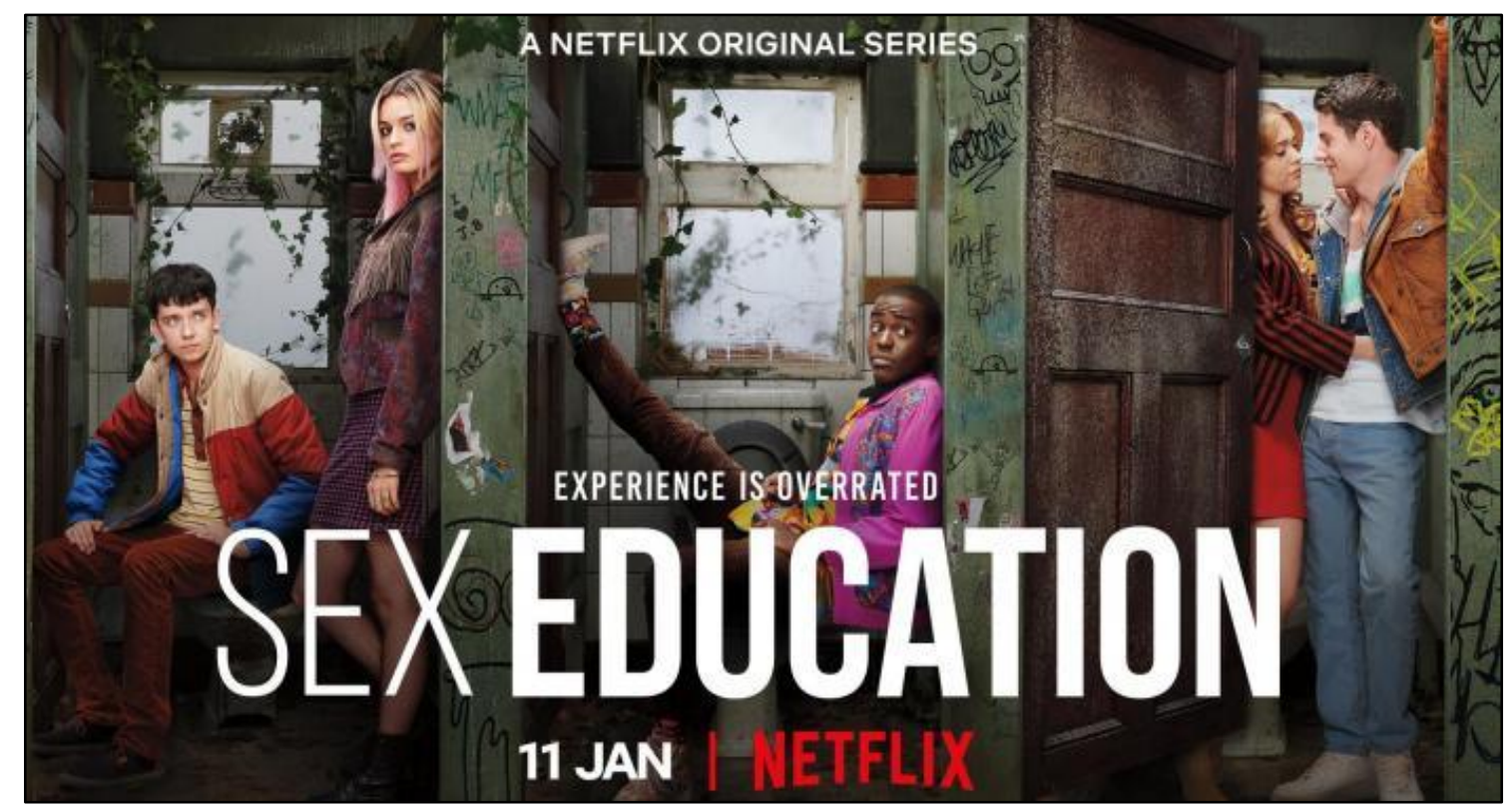

Gambar 1. Poster Serial Netflix Sex Education

Sex Education berseting di kota kecil di Inggris yang terkesan retro lewat kostum, kendaraan, dan soundtrack. Namun, serial ini berlatar di zaman sekarang dan tidak selalu fokus pada klinik seks berbayar milik Otis dan Maeve. Serial ini memberikan porsi yang pas untuk membahas masing-masing karakter pendukung dengan segala permasalahan mereka (Lence, 2019). Setiap permasalahan mereka mengangkat isu kekinian yang relevan tentang bagaimana remaja mencari jati diri mereka (terutama Eric yang diperankan oleh Ncuti Gatwa) dan bagaimana lingkungan melihat hal itu, baik itu dari dari segi pendidikan, hobi, atau orientasi seksual (Zahn, 2020). 
Pada penelitian ini, berdasarkan hasil wawancara dengan para informan, peneliti menemukan beberapa respon dan tanggapan yang beragam mengenai serial Sex Education ini. Menurut hasil wawancara didapatkan bahwa remaja yang memiliki analisis yang cukup baik terhadap serial ini, antara lain: pada informan pertama ini bernama Lili yang berusia 17 tahun asal Solo Provinsi Jawa Tengah, menurutnya serial Netflix kali ini memang sangatlah terang-terangan dalam mempertontonkan adegan seksual, baik visual, maupun verbal. Bikin yang nonton jadi canggung. Canggung dalam artian pada saat ada scene yang terlalu vulgar tanpa disensor, selebihnya informan cukup menikmati jalan ceritanya yang sangat menghibur dan menarik. Adapun pada informan kedua bernama Holis yang berusia 17 tahun asal Banjarmasin Provinsi Kalimantan Selatan, menurutnya untuk menonton serial ini harus dengan pikiran yang terbuka (open minded). Sex Education tidak hanya membicarakan tentang sex, akan tetapi banyak pelajaran dan pesan moral yang dapat diambil dari kisah para karakter. Permasalahan yang diangkat cukup mewakili realita yang terjadi serta tidak lupa pula menampilkan cerita remaja (itu sendiri) yang segar dan fun hal ini memberikan alur dengan porsi yang cukup seimbang. Kemudian pada informan ketiga bernama Theo yang berusia 17 tahun asal Bandung Provinsi Jawa Barat, menurutnya alur ceritanya cukup dapat dinikmati. Karakternya juga menarik dan dikembangkan dengan baik. Menurut informan, disini tidak ada karakter yang bener-bener jahat. Konfliknya juga tidak terbelit-belit. meskipun masih banyak yang menganggap tabu, namun pendidikan seks merupakan satu dari banyaknya hal di dunia ini yang harus mulai diketahui dan disadari sedari remaja. Hanya saja, kultur di negara kita tampaknya belum seterbuka di serial tersebut.

Berdasarkan dari hasil wawancara diatas, dapat dilihat bahwa serial ini bisa dijadikan pembelajaran sebab dari serial ini terdapat banyak informasi tentang pendidikan seksual yang mana peran tersebut terkait dengan perasaan ingin tahu remaja melalui pemberian informasi yang benar kepada remaja berkaitan dengan seksualitas. Pemberian informasi ini terdiri dari 3 (tiga) komponen yang berhasil diidentifikasi dari hasil wawancara untuk diberikan sebagai materi pendidikan seksual bagi remaja, yaitu informasi yang berkaitan dengan:

Pertama, perubahan dan perkembangan fisik, mental, dan kematangan emosional yang berkaitan dengan masalah seksual pada remaja. Adanya kecenderungan orang tua yang terkesan tidak peduli dengan permasalahan yang dihadapi remaja dalam masa 
transisinya juga mengakibatkan pendidikan seksual bagi remaja harus diisi dengan materi yang berkaitan dengan gejala-gejala yang dialaminya di masa transisinya. Gejala-gejala tersebut misalnya terjadinya menstruasi bagi remaja putri dan emisi nokturnal (mimpi basah) bagi remaja putra, pertumbuhan rambut pubis, pertumbuhan penis dan payudara, dan lain-lain. Melalui materi pendidikan seksual bagi remaja diharapkan agar apa yang tidak didapat anak di rumah, dapat diperolehnya di sekolah. Selain itu, dengan adanya informasi pengetahuan seksual yang berisikan konsep diri, inteligensi, dan juga peran sosial diharapkan remaja dapat lebih baik dalam memilih dan mempercayai teman dan mengerti tentang batasan-batasan dalam pergaulan, sehingga mereka tidak ikut terjerumus dalam pengaruh negatif teman dan lingkungannya. kesalahan dan penyimpangan seksual yang dapat mengganggu Kesehatan fisik dan mental remaja (Ahmad, 2017).

Kedua, pendidikan seksual juga harus memberikan informasi yang baik dan benar mengenai kesalahan dan penyimpangan seksual yang dapat mengganggu Kesehatan fisik dan mental remaja. Kesalahan dan penyimpangan tersebut meliputi beberapa hal yaitu ketergantungan pada pornografi, pacaran sampai melakukan rangkulan dan ciuman, phonesex, dan sharing foto telanjang. Remaja yang sedang dalam proses belajar mengajar, dikarenakan ketergantungannya terhadap pornografi, begitu mudah hilang fokus dari materi yang sedang disampaikan oleh gurunya. Hal ini tentu berpengaruh pada kestabilan prestasi remaja tersebut. Oleh karena itu, remaja perlu diberikan informasi mengenai pornografi yang dapat menyebabkan ketergantungan dan pada akhirnya dapat mengganggu mental dan masa depannya.

Ketiga, dampak negatif pergaulan bebas dan perilaku seksual dini. Remaja perlu diberikan informasi tentang dampak negatif pergaulan bebas dan perilaku seksual dini, seperti kehamilan yang tidak diinginkan (KTD), aborsi, HIV/AIDS, putus sekolah, penyakit menular seksual dan penyakit kelamin. Hal ini disebabkan karena meski sudah ada mata pelajaran biologi yang menjelaskan mengenai kesehatan reproduksi, masih ada remaja yang belum mengetahui hal-hal yang dapat mengakibatkan kehamilan pada remaja dan dampak negatif perilaku seksual dini lainnya. Remaja yang memiliki pengetahuan yang cukup mengenai hal apa saja yang dapat menyebabkan kehamilan beserta dengan risiko atas kehamilannya, tentu tahu bagaimana cara agar tidak hamil, salah satunya adalah dengan meningkatkan kontrol dirinya dalam menghindari perilaku 
seks bebas maupun seks pranikah. Cara lainnya ialah dengan selalu mengingat risiko dan tanggung jawab yang harus diembannya apabila dia hamil ataupun menghamili.

Informasi yang benar yang berkaitan dengan seksualitas yang diberikan pada remaja akan menjawab pertanyaan-pertanyaan yang muncul dari rasa ingin tahu pada remaja. Menurut pendapat salah satu informan penelitian ini, informasi-informasi yang berkaitan dengan seksualitas yang didapatnya dari berbagai sumber akurat, memberikan dampak yang positif untuk menjaga rasa ingin tahu terkait dengan seksualitas yang dimilikinya. Informasi-informasi yang didapat remaja melalui pendidikan seksual mampu menjadi tameng dalam mengontrol rasa ingin tahu yang muncul dalam dirinya. Melalui informasi yang didapatnya tersebut, remaja ini jadi mengerti bahwa apabila dia terus menuruti rasa ingin tahunya, maka kemungkinan dia akan terjerumus dalam perilaku seksual menyimpang seperti seks bebas dan pranikah.

Informasi yang benar tersebut disampaikan secara sederhana agar dapat dipahami dan dapat diterima oleh setiap remaja yang mendengarnya. Hal ini disebabkan karena remaja sebagai objek yang menerima informasi memiliki tingkat pemahaman yang berbeda-beda. Ada remaja yang mengerti materi hanya dengan sekali penyampaian, ada juga yang harus mendengarkan berkali-kali baru bisa mengerti, bahkan ada juga yang salah mengerti materi yang disampaikan. Kondisi perbedaan tingkat pemahaman inilah yang menjadi salah satu alasan bagi sekolah untuk tidak memberikan Pendidikan seksual secara luas kepada remaja. Namun hal ini tidak menjadi alasan agar remaja tidak diberikan pendidikan seksual. Mengingat pentingnya memberikan informasi seluasnya bagi remaja agar terhindar dari rasa penasaran dan ingin mencari tahu ke sumber lain yang belum tentu akurat, hal ini tentu harus dihindari. Pendidikan seksual yang memberikan informasi secara luas mengenai seksualitas bagi remaja tetap harus diberikan, namun dengan cara penyampaian yang lebih sederhana sehingga dapat dicerna oleh seluruh remaja yang menerima informasi tersebut. Adapun peran pembentukan sikap positif remaja tersebut terkait dengan situasi remaja menghadapi perilaku seksual dini dan pranikah. Hal tersebut dapat dilakukan dengan 2 (dua) cara, yaitu:

Pertama, mengajak remaja untuk menyalurkan energi dan waktunya guna hal-hal yang positif. Kecenderungan terjadinya perilaku seksual menyimpang dapat terjadi salah satunya karena adanya rasa ingin tahu dan waktu luang yang berlebih. Remaja yang sedang berada dalam masa transisi dari anak-anak menuju dewasa selalu dihadapkan pada 
rasa ingin tahu terhadap berbagai hal. Tidak jarang rasa ingin tahu tersebut tidak mendapatkan jawaban yang masuk ke dalam pikiran remaja baik dari orang tua, guru, maupun lingkungannya. Hal ini menyebabkan remaja tersebut mencari jawaban sendiri yang belum pasti benar dan justru ada kemungkinan menyesatkan. Besarnya rasa ingin tahu yang disertai dengan waktu luang yang banyak dan ketidaktahuan remaja untuk mengisinya dengan kegiatan apa, menyebabkan tidak sedikit remaja yang menghabiskan waktu luangnya untuk mengakses hal-hal yang berbau pornografi di internet. Pada akhirnya, remaja yang memiliki pengetahuan kurang mengenai pendidikan seksual, akan menghabiskan waktunya untuk mengakses hal yang berbau pornografi dan melampiaskan rasa ingin tahunya dengan melakukan onani dan perilaku- perilaku seksual lainnya (Nadeak, 2020).

Kedua, mengajak remaja menjauhkan diri dari perilaku seks bebas dan di luar nikah beserta dengan dampak-dampak negatifnya. Melalui informasi dan pemahaman tentang risiko dan tanggung jawab yang harus dipikul remaja yang melakukan penyimpangan seksual, terbentuklah remaja yang mampu mengontrol dirinya dalam hal yang berkaitan dengan seksualitas yang ditimbulkan oleh hormon-hormonnya yang sedang berkembang (Wahyuningsih, 2017). Dari serial tersebut tentu saja sudah bisa menjadi gambaran kalau sex yang tidak aman bisa berakibat fatal dan bisa saja merugikan banyak pihak.

Pengetahuan menjadi sebuah dasar bagi tindakan yang dilakukan individu. Apa yang orang ketahui akan mempengaruhi perilakunya. Pengetahuan merupakan faktor yang penting dalam menentukan perilaku individu (Mutiani, 2017). Pengetahuan dapat secara langsung mempengaruhi perilaku. Sebagai contoh, apabila seorang remaja perempuan mengetahui bahwa setiap hubungan seksual dapat mengakibatkan kehamilan, maka dia akan menghindarkan dirinya dari hubungan seksual. Namun jika dia tidak memiliki pengetahuan mengenai hubungan seksual tersebut, apabila ada ajakan atau dorongan dari luar dirinya, maka bisa jadi dia akan melakukan hubungan seksual tersebut.

Pengetahuan juga dapat mempengaruhi perilaku secara tidak langsung dengan mempengaruhi norma, nilai, sikap, cara pandang, dan efikasi diri seorang remaja. Sebagai contoh, apabila remaja tidak mengetahui pandangan orang tuanya mengenai hubungan seksual di kalangan remaja, maka pandangan mereka tentang hubungan seksual di 
kalangan remaja tersebut akan dibentuk oleh teman dan media. Hal ini akan membuka kesempatan terjadinya perilaku seksual dini pada remaja (Rinta, 2015).

Dari serial tersebut meperlihatkan bahwa intensitas komunikasi yang tinggi dengan teman sebaya mengenai seks secara praktis meningkatkan risiko inisiasi hubungan seks pranikah pada usia lebih dini hamper dua kali lipat terutama pada informan laki-laki. Damayanti (2018) menyatakan bahwa perilaku seks pranikah cenderung dilakukan karena pengaruh teman sebaya yang negatif dan pada akhirnya remaja mengadakan percobaan dengan jalan masturbasi, bercumbu atau berhubungan seksual. Pengetahuan remaja tentang seksualitas dan kesehatan reproduksi terutama didapatkan dari teman sebaya. Sumber informasi yang diperoleh dari teman sebaya lebih mudah diterima oleh remaja karena mereka berbicara dengan gaya bahasa yang sama dan menghadapi masalah yang sama. Sesuai dengan teori psikososial menyatakan bahwa pengetahuan dan keterampilan remaja dapat meningkat bila mereka diberi kesempatan untuk meniru perilaku orang yang mempunyai ketertarikan dengannya. Pengaruh teman sebaya dapat menciptakan keterikatan, kebersamaan, sehingga remaja seringkali sulit melepaskan diri dari kelompok teman sebayanya.

\section{SIMPULAN}

Berdasarkan dari pembahasan sudah di jabarkan, penulis menyimpulkan bahwa serial Netflix Sex Education memiliki peran sebagai bahan pembelajaran para remaja khususnya pada jenjang Sekolah Menengah Atas di Indonesia sebab pada era modern saat ini remaja bisa terbawa pergaulan bebas khususnya pada hubungan seksual yang salah. Dari serial ini terdapat banyak pembelajaran yang bisa diambil seperti pendidikan seksual pada remaja, pentingnya memahami dampak sex bebas dan tidak aman, serta memahami dan mempelajari beberapa orientasi seksual yang dimiliki orang setiap orang. Hal tersebut sangat penting untuk diketahui mengingat anak remaja pada saat ini sangat memiliki jiwa rasa ingin tahu yang sangat tinggi. Melalui informasi yang didapatnya tersebut, remaja ini jadi mengerti bahwa apabila dia terus menuruti rasa ingin tahunya, maka kemungkinan dia akan terjerumus dalam perilaku seksual menyimpang seperti seks bebas. 


\section{DAFTAR PUSTAKA}

Abbas, E. W., Susanto, H., Irmawati, I., \& Akmal, H. (2021). Media Film Dokumenter dan Pengaruhnya Terhadap Keterampilan Berpikir Kritis Siswa. HISTORIA: Jurnal Program Studi Pendidikan Sejarah, 9(1), 65-78.

Abbas, E.W., Harlie, M., \& Rajiani, I. (2019). Managing information systems by integrating information systems success model and the unified theory of acceptance and usage of technology. Polish Journal of Management Studies, 20.

Ahmad, D. N. (2017). Pengaruh pendidikan seksual dalam keluarga terhadap perilaku penyimpangan dan pelecehan seksual pada remaja. Jurnal Pelangi, 9(2).

Blea, J., Enos, M., Izumigawa, K., Sanchez, S., \& Tinsley, E. (2020). Netflix Case Study: Recovering from the Global Cuties Crisis. TIMELINE, $3,1$.

Damayanti, M., Anni, C. T., \& Mugiarso, H. (2018). Layanan informasi dengan media gambar untuk meningkatkan pemahaman sex edukation siswa. Indonesian Journal of Guidance and Counseling: Theory and Application, 7(1).

Forni, D. (2020). Young adults and TV series. Netflix and new forms of serial narratives for young viewers. MeTis-Mondi educativi. Temi indagini suggestioni, 10(1), 296-312.

Handy, M. R. N. (2021). Pembelajaran Sejarah Dalam Membangun Historical Awarness dan Sikap Nasionalisme Pada Peserta Didik. Prabayaksa: Journal of History Education, 1(1), 49-54.

Lence, F. P. (2019). Sex Education: la educación sexual integral en Netflix. Comunicación y género, 2(1), 121-134.

Mutiani, M. (2017). IPS dan pendidikan lingkungan: urgensi pengembangan sikap kesadaran lingkungan peserta didik. SOSIO-DIDAKTIKA: Social Science Education Journal, 4(1), 45-53.

Nadeak, B., Sormin, E., Naibaho, L., \& Deliviana, E. (2020). Sexuality in Education Begins in The Home (Pendidikan Seksual Berawal Dalam Keluarga). Jurnal Comunita Servizio, 2(1), 254-264.

Rinta, L. (2015). Pendidikan seksual dalam membentuk perilaku seksual positif pada remaja dan implikasinya terhadap ketahanan psikologi remaja. Jurnal Ketahanan Nasional, 21(3), 163-174. 
Rusmaniah, R., Mardiani, F., Handy, M. R. N., Putra, M. A. H., \& Jumriani, J. (2021). Social Services Based on Institutional for Youth Discontinued School. The Innovation of Social Studies Journa1, 2(2), 151-158.

Wahyuningsih, D. D. (2017, July). Pendidikan seksualitas pada remaja melalui media pembelajaran. In Prosiding Seminar Nasional Bimbingan dan Konseling (Vol. 1, No. 1, pp. 46-51).

Zahn, J. (2020). Cultural Filter? Netflix'Sex Education in an English-German context: A cross-cultural comparative analysis of English and German translation (Master's thesis). 